\title{
The Bidirectional Spirituality Scale: Construction and Initial Evidence for Validity
}

\author{
W. Paul Williamson ${ }^{1} \odot$ \\ Henderson State University
}

\author{
Aneeq Ahmad ${ }^{2} \odot$ \\ Henderson State University
}

\begin{abstract}
This study presents the development and construction of the 16-item Bidirectional Spirituality Scale (BSS), which is based on the theory of vertical and horizontal spirituality. Vertical spirituality focuses on that involving one's relationship with God, whereas horizontal spirituality is concerned with one's relations with people and attunement to meaning and purpose. Using data from 239 USA participants, exploratory factor analysis has produced three factors: vertical spirituality (VS; 8 items); horizontal spirituality-others (HS-O; 4 items); and horizontal spirituality-existential (HS-E; 4 items). A partial confirmatory factor analysis has confirmed the three-factor model. For research purposes, HS-O and HS-E can be combined to produce an 8-item horizontal spirituality scale to complement the 8-item VS scale. Further analyses have found preliminary evidence for both convergent and discriminant validity. Because of its sound psychometric properties, the BSS appears to be a useful, brief instrument for discriminating both religious and non-religious spirituality.
\end{abstract}

Keywords:

Spirituality scales $\bullet$ Spirituality $\bullet$ Religious spirituality $\bullet$ Non-religious spirituality $\bullet$ Partial confirmatory factor analysis

İki Yönlü Maneviyat Ölçeği: Geliștirme Süreci ve Geçerliliğe İlişkin İlk Kanıtlar

$\ddot{\mathrm{O} z}$

Bu çalışmada, dikey ve yatay maneviyat teorisine dayanan 16 maddelik İki Yönlü Maneviyat Ölçeğinin geliștirilmesini sunulmaktadır. Dikey maneviyat, kişinin Tanrı ile ilişkisine odaklanırken, yatay maneviyat, birinin insanlarla ilişkileri ve anlam ve amaçlara uyumu ile ilgilidir. 239 ABD'li katılımcılarından gelen veriler kullanarak yapılan açımlayıcı faktör analizinde üç faktör üretmiștir: dikey maneviyat (8 madde); yatay maneviyat-diğerleri (4 madde); ve yatay maneviyat-varoluşsal (4 madde). Kısmi bir doğrulayıcı faktör analizinde, üç faktörlü model doğrulanmıştır. Araştırma amaçlanı için, yatay maneviyat-diğerleri ve yatay maneviyat-varoluşsal alt ölçekleri, 8 maddelik Dikey Maneviyat Ölçeğini tamamlamak için 8 maddelik bir yatay maneviyat ölçeği oluşturmak için birleştirilebilmektedir. Sağlam psikometrik özelliklerinden dolayı İki Yönlü Maneviyat Ölçeği, hem dini hem de dini olmayan maneviyatı ayırt etmek için kısa ve kullanışlı bir araç olarak görülmektedir.

Anahtar Kelimeler

Maneviyat ölçekleri • Maneviyat • Dini maneviyat• Din dışı maneviyat • Kısmi doğrulayıcı faktör analizi.

1 Correspondence to: W. Paul Williamson, Department of Psychology, HSU Box 7854, Henderson State University, Arkadelphia, AR 71999. Contact: williaw@hsu.edu

2 Department of Psychology, Henderson State University, Arkadelphia, AR 71999.

Citation: Williamson, W. P., \& Ahmad, A. (2019). The Bidirectional Spirituality Scale: Construction and initial evidence for validity. Spiritual Psychology and Counseling 4, 7-23. http://dx.doi.org/10.12738/spc.2019.4.1.0057 
Spirituality has become a phenomenon of increasing interest in the psychology of religion. Had William James (1902/1982) written The Varieties of Religious Experience in recent times, one could say he might have entitled it, The Varieties of Spiritual Experiences. Although both religion and spirituality have been meaningful concepts over the history of human experience, a tendency in past decades has existed to discriminate their meanings, particularly in Western culture (Zinnbauer \& Pargament, 2005). Accordingly, more people now are making the distinction between being religious and being spiritual, although some experience a spirituality that is religiously defined and thus claim to be both religious and spiritual to varying degrees. In the history of psychological research, a consensus of agreement has yet to exist on definitions for these important phenomena, and consequently investigators are becoming more aware of the need to better operationalize these constructs when developing their research instruments. Thus the purpose of this study is to introduce a research tool based on relevant theory that allows for better discrimination of religious and non-religious spirituality.

\section{Measures of Spirituality}

Over recent decades, several scales have been developed for measuring spirituality, although many were constructed largely for clinical use (e.g., Daaleman \& Frey, 2004; Delaney, 2005; Fang, Li, Lai, Lin, Bridge, \& Chen, 2011; Peterman, Fitchett, Brady, Hernandez, \& Cella, 2002; Vivat et al., 2013; World Health Organization, 2002). For the purposes here, however, we mainly are concerned with instruments that have been used to advance research on spirituality within the larger context of psychology and religion. We will briefly describe a few of these here.

One of the earliest instruments developed for measuring spirituality is the Spiritual Well-Being Scale (SWBS; Paloutzian \& Ellison, 1982). With a backdrop of concern for loneliness and quality of life, the authors constructed 20 items to assess two aspects of spiritual well-being: a vertical dimension that describes religious wellbeing (RWB), and a horizontal dimension that connotes existential well-being (EWB), or life satisfaction and purpose. Both factors together assess overall spiritual well-being. The SWBS has been widely used in general research but also has been employed in research among psychiatric patients and inmates (Bufford, Paloutzian, \& Ellison, 1991), as well as those recovering from substance addiction (Williamson $\&$ Hood, 2016). Although well-used, some studies have been unable to confirm the two-factor structure of the SWBS (Ledbetter, Smith, Fischer, Vosler-Hunter, \& Chew, 1991; Scott, Agresti, \& Fitchett, 1998). Furthermore, the recent move to publish the instrument as a proprietary test has discouraged some investigators from using the SWBS in general research. 
Other spirituality scales have since emerged for general research, although some might be found useful in clinical settings. Piedmont (1999, p. 988) defined spiritual transcendence as "the capacity of individuals to stand outside of their immediate sense of time and place to view life from a larger, more objective perspective." With this notion, he consulted various religious texts when developing the 24-item Spiritual Transcendence Scale (STS), which assesses the construct along three dimensions. Prayer fulfillment depicts the transcending effects of prayer and its association with joy, peace, contentment, and spiritual growth. Universality is a factor that describes belief in a higher realm that transcends the present world and brings meaning and interconnectedness with others and life. As the third factor, connectedness is concerned with the degree of personal responsibility felt for one's heritage, including people in the past, present, and future. Together, the three factors provide a composite that reflects a more encompassing dimension of spirituality that Piedmont called global transcendence.

The Sources of Spirituality Scale (SOSS) is an 18-item instrument based on a relational model of spirituality observed among human relationships that has been applied to spiritual experiences with the Sacred (Davis et al., 2015). The instrument itself includes five different factors, each of which depicts a different type of spirituality. The theistic factor assesses the relation with some higher entity, whereas the nature factor measures the connection with natural surroundings. Human spirituality is concerned with one's relation to humanity, and transcendent spirituality focuses on the more ineffable encounters with something beyond the material realm. Finally, self-spirituality measures the degree to which one has connected with a deep and genuine sense of self without involving a sense of divine self. Although these factors assess various aspects of spirituality, their combined scores reflect the general construct of spirituality.

A more recent spiritual well-being instrument is the Spiritual Well-Being Questionnaire (SWBQ; Gomez \& Fisher, 2003). Its 20 items are based on the earlier work of Fisher (1998), which Gomez and Fisher used to operationalize the construct; essentially, spiritual well-being is characterized as living harmoniously "within relationships with oneself (personal), others (communal), nature (environment), and God (or transcendental other)" (p. 1976). These four relationship qualities represent the factors that constitute the SWBQ. More specifically, personal wellbeing is concerned with self-awareness and self-identity, whereas communal wellbeing involves the nature of personal relationships, including concerns with love, respect, and trust. Interest in developing connections with nature and the environment characterize environmental well-being, while transcendental well-being describes the quality of one's relationship with God. The authors claim the SWBQ to be distinct from other spiritual well-being measures because of being a more broad-based theory, as proposed by Fisher (1998). 
At least two spirituality instruments have been developed for use in non-American cultures. Based largely on Piedmont's (1999) theory of spiritual transcendence, the 22-item Scale of Spiritual Transcendence (SST; Piotrowski, Skrzypińksa, \& Żemojtel-Piotrowska, 2013) was developed in Poland and includes two subscales. The factor of transcendence proper contains items that describe one's connectedness to a higher reality and humanity, meaning in life, and the positive effects of spiritual practices, whereas items in the factor of spiritual oneness characterize the tendency to accept others and even paradoxical experiences in life. Constructed for use in Turkey, the Spiritual Well-being Scale (SWBS; Ekşi \& Kardaş, 2017) contains 29 items based on a survey of various definitions on spiritual well-being. Although not described in great detail, the three factors comprising this instrument include transcendence, harmony with nature, and anomie. Unlike the above SST, the SWBS is available for research only in its cultural language.

All the above instruments have been developed for assessing spirituality based on various theories or definitions of the construct, and their authors have reported acceptable psychometric properties to varying degrees.

\section{A Two-Dimensional Approach to Spirituality}

Hood, Hill, and Spilka (2009, p. 282) observed from research that a twodimensional approach to understanding spiritual transcendence might be useful. A vertical transcendence may apply to those who affirm a God-conscious spirituality, whereas a horizontal transcendence may best characterize others who reject the notion of God yet experience interconnectedness with phenomena encountered along a more horizontal plane, such as with nature, various social movements, and the like. More recently, Streib and Hood (2016, pp. 11-12) offered a distinction between vertical and horizontal transcendence in terms of explicit and implicit religion, as is observed particularly in Western culture. Explicit religion describes a spirituality that relates to an "above world" inhabited with supernatural agents and/or some deity. Implicit religion, however, involves a transcendence experienced by the nonreligious, including some agnostics and atheists, all of whom may identify as spiritual but not religious. Accordingly, explicitly religious persons, who recognize the reality of God or some deity, experience a vertical dimension of spirituality, while those who do not encounter a spirituality or connectedness along a horizontal dimension in the present world. Streib and Hood (2016) also acknowledged a "middle ground" between vertical and horizontal transcendence that may include an overlapping of the two (e.g., spiritual experiences among new religious movements, charismatic and esoteric groups, etc.); these may not be necessarily vertical or horizontal. For our purposes here, however, we are concerned only with the vertical and horizontal dimensions of transcendence or spirituality. 
Based on this two-dimensional approach (Hood et al., 2009; Streib \& Hood, 2016), the intent of this study is to develop a bidirectional spirituality scale that is theoretically distinct from the other spiritual assessments discussed above. With respect to vertical spirituality, our concern is for a scale that assesses the quality of one's relationship with God specifically. The horizontal scale, however, will measure spirituality in terms of two factors that are not necessarily religious: the quality of interpersonal relationships and one's personal attunement to existential meaning and purpose in the world. Because of its vertical and horizontal dimensions, we anticipate that this instrument might be useful for assessing both religious and non-religious spirituality. We expect the religious will relate to both vertical and horizontal dimensions of spirituality while the non-religious will more likely relate to the horizontal than the vertical dimension. Higher scores along both dimensions will reflect a greater degree of spirituality and, implicitly, spiritual wellness.

\section{Method}

\section{Participants}

Our sample included 239 students from a small state university in the southern USA. They came from general psychology and cross-cultural psychology classes and were given extra credit by their instructors for participating. The participants ranged from 1847 years of age $(M=20.96, S D=4.44)$, with $71.1 \%$ being women (1 participant gave no gender response). About $87 \%$ identified as Christian, with the two largest groups being Baptist (49\%) and non-denominational (10\%), while the remaining $28 \%$ identified among several other Christian groups. Among the $13 \%$ of non-Christian participants, $7.5 \%$ were agnostics, $3.8 \%$ were atheists, and $2.4 \%$ were a member of a non-Christian religion.

In response to the item, "I consider myself to be a religious person" ( $1=$ strongly disagree; $5=$ strongly agree), participants scored an average rating of $3.65(S D=$ 1.17). To the item, "I consider myself to be a spiritual person" ( $1=$ strongly disagree; $5=$ strongly agree), participants averaged a score of $3.87(S D=1.03)$. Based on a paired-samples $t$-test, participants perceived themselves as significantly more spiritual than religious $\left(t_{(238)}=-3.4, p<.001\right)$.

\section{Instruments}

Religious Orientation. We assessed religious motivation with Gorsuch and McPherson's (1989) indices, one each for intrinsic and extrinsic religious orientation. The intrinsic item was modified to: "My whole approach to life is based on my religion or spirituality" ( $1=$ strongly disagree, $5=$ strongly agree $)$. The extrinsic item was revised to: "I go to church/spiritual events mainly because I enjoy seeing people I know there" ( 1 = strongly disagree, $5=$ strongly agree $)$. 
Bidirectional Spirituality Scale (BSS). As discussed above, we were interested in developing a brief multi-dimensional spirituality instrument with three factors: (1) vertical spirituality in relation to God; (2) horizontal spirituality in relation to other people; and (3) horizontal spirituality in relation to existential meaning in the world. With this in mind, we constructed 30 items representing these content areas and presented each with a 7-point rating scale $(1=$ strongly disagree, $7=$ strongly agree). The instructions for participants were as follows:

Please read each statement below very carefully and click your level of agreement on how it relates to your personal life. Do not make your judgment based on how you would like it to relate to you, but how it honestly relates to you.

The BSS included both pro- and contra-items, and contra-items were reversescored before their use in the factor analyses. The emergent scales were constructed by summing their respective items, with higher scores indicating higher levels of spirituality (see Table 1 for BSS items).

Beck's Depression Inventory (BDI). Widely used for measuring depression, the BDI (Beck, Ward, Mendelson, Mock, \& Erbaugh, 1961) is an instrument with 21-items, each of which presents a series of four statements that progressively indicate higher levels of depression. Each item was scored from 0 to 3, and the sum of all items produced a composite where higher scores reflect depression's characteristic attitudes and symptoms. The reliability of the BDI for this study was .94.

Self-Esteem Scale (SES). We used Rosenberg's (1965) SES to assess participants' subjective views of themselves. Based on a 4-point rating scale $(0=$ strongly disagree, 3 = strongly agree), the scale is a 10 -item unidimensional instrument that measures positive and negative feelings about oneself (e.g., "I feel that I have a number of good qualities."). After reverse scoring contra-items, we summed all item-scores to produce a composite where higher scores indicate higher self-esteem. Its reliability coefficient in this study was .89 .

Ego Loss Scale (ELS). To assess weakness of ego strength, we used the Ego Loss subscale of the Exceptional Experiences Questionnaire (Kohls, Hack, \& Walach, 2008), which assesses the frequency and evaluation of exceptional and spiritual experiences. The ELS includes 12 items, each of which is presented with a 5-point rating scale $(1=$ Never, $2=$ Seldom, 3 = Sometimes, 4 = Often, $5=$ Very often). An example from the ELS is: "A feeling of ignorance or not knowing is overwhelming to me." For this study, we assessed only the frequency of such experiences. We calculated a composite score by summing all item ratings, with higher scores reflecting weaker ego strength. Its reliability in this study was .92 .

God Mysticism Scale (GMS). We measured reports of mysticism using a brief version of the God Mysticism Scale (Hood \& Williamson, 2000). The original 
instrument is a 32-item scale with three subscales that measure introvertive mystical experiences, extrovertive mystical experiences, and the interpretation of these mystical experiences. The introvertive subscale assesses an inner mysticism involving a withdrawal from the world and sensory experience, whereas the extrovertive subscale measures an outer mysticism concerning unity with all things in the world. The interpretation subscale assesses the meaning of the mysticism types in terms of sacred and affective qualities.

To use a briefer version of the scale, we performed an exploratory factor analysis of the original data and selected 4 of the highest loading items ( 2 pro-traits and 2 contraits) from each of the three factors. This resulted in a 12-item GMS that assesses introvertive mystical experiences, extrovertive mystical experiences, and their interpretation of those experiences. An example of an extrovertive item is: "I have had an experience in which I realized the oneness of myself and all things in God." A 9-point rating scale is presented with each item $(1=$ strongly disagree, $9=$ strongly agree). After recoding the con-trait items, we summed the scores of all 12 items to produce a composite, with higher scores reporting more mystical experiences. The reliability of the GMS in this study was .88 .

Penn State Worry Questionnaire (PSWQ). The widely-used PSWQ (Meyer, Miller, Metzger, \& Borkovec, 1990) includes 16 statements that describe variations of the tendency to worry (e.g., "My worries overwhelm me."), and each statement is presented with a 5 -point rating scale $(1=$ not at all typical of me, $5=$ very typical of me). We computed a composite score by reverse-scoring con-trait items and then summing all item scores. A higher score indicates a greater tendency to worry. The reliability of the PSWQ for this study was .92 .

Happiness Scale (HS). The HS (Lyubomirsky \& Lepper, 1999) measures subjective happiness through the use of four items presented with a 7-point rating scale (e.g., "In general, I consider myself" ( $1=$ not a very happy person, $7=$ a very happy person). After reverse-scoring one con-trait item, we computed a composite score by summing all four items; higher scores reflect higher levels of subjective happiness. The reliability of the HS in this study was .87 .

Life Orientation Test (LOT). The LOT (Scheier, Carver, \& Bridges, 1994) includes six items along with four filler items that are scored. Three items measure optimism and three assess pessimism, with higher scores indicating higher levels of optimism/pessimism. All items are presented with a 5-point rating scale $(1=$ strongly disagree, 5 = strongly agree), with some following examples: "In uncertain times, I usually expect the best" (optimism); and "If something can go wrong for me, it will" (pessimism). The reliabilities for optimism and pessimism on the LOT in this study were .72 and .76 , respectively. 
Satisfaction with Life Scale (SLS). The SLS (Diener, Emmons, Larsen, \& Griffin, $1985)$ is a 5-item survey that measures cognitive judgments about life satisfaction (e.g., "In most ways my life is close to my ideal."). A 7-point rating scale ( 1 = strongly disagree, $7=$ strongly agree) is presented with each item. Ratings for all items were summed to compute a single score with higher scores indicating more satisfaction with life. The reliability of the SLS in this study was .84 .

\section{Procedure}

Upon approval of this study from our Institutional Review Board, we assembled the protocol for the above instruments in SurveyMonkey for collecting research data. We contacted Instructors in our department about the study and asked if they would offer extra credit to their students for participation. We then emailed instructors the link to the survey website for distribution to their students.

Once the link was accessed, the first page presented participants with informed consent concerning a description of the study, promised anonymity, risks, and benefits; furthermore, it stated that they could withdraw from participation at any time without penalty (i.e., without loss of course extra credit). At the bottom of this page, participants were required to click a box indicating they agreed to participate before gaining access to the subsequent pages on demographic items and survey instruments. According to SurveyMonkey, the average time for participation was 16 minutes.

\section{Results}

\section{Data Preparation}

Our initial sample included 255 participants; however, we deleted 16 participants from the sample who had omitted responses to more than eight survey items or who had omitted an entire scale. For the remaining participants, we computed the variable mean to substitute for any missing values. This process left us a sample of 239 participants with complete data for our analyses. We performed all data analyses with IBM SPSS software, version 22.

\section{Exploratory Factor Analysis (EFA)}

Our major concern was to develop a brief Bidirectional Spirituality Scale (BSS) with 3 factors that assess (1) vertical spirituality (VS) in relation to God; (2) horizontal spirituality-others (HS-O) in relation to other people; and (3) horizontal spiritualityexistential (HS-E) in relation to one's place of being the world. Our thinking is also that both the HS-O and HS-E factors can be combined as a Horizontal Spirituality (HS) factor in corollary with VS. 
We included all $30 \mathrm{BSS}$ items in an EFA to determine the initial structure, using principal axis factoring as the method of extraction and varimax rotation. As revealed by the scree plot (eigenvalues $>1$ ), the initial solution identified four factors that accounted for $58.81 \%$ (Factor $1=30.56 \%$, Factor $2=12.3 \%$, Factor $3=11.7 \%$, Factor $4=4.25 \%$ ) of the variance in scores (see Table 1). All items from Factor 1 appeared to describe a spiritual relationship with God. Concerning Factor 2, all items except for Item 25 appeared to describe spiritual relations with other people. With the exception of Items 10 and 3, Factor 3's items were concerned with existential issues that can be described as spiritual in nature. Factor 4 included only three items, one of which was about personal relations while two others described existential concerns.

Table 1.

Initial Factorial Structure of the Bidirectional Spirituality Scale based on the Exploratory Factor Analysis of 30 Items $(\mathrm{N}=239)$

\begin{tabular}{|c|c|c|c|c|c|}
\hline \multirow{2}{*}{ Item } & \multirow[b]{2}{*}{ Items } & \multicolumn{4}{|c|}{ Factors } \\
\hline & & I & II & III & IV \\
\hline & When I engage in spiritual or religious practices, I feel drawn to God. & .903 & & & \\
\hline & I often have the sense that God is with me. & .900 & & & \\
\hline & I often feel close to God. & .886 & & & \\
\hline & I am fully confident that God is directing my life. & .874 & & & \\
\hline & I know beyond all doubt that God loves me. & .870 & & & \\
\hline & I feel a peacefulness when I think about God. & .867 & & & \\
\hline 12. & I know that God hears me when I pray. & .864 & & & \\
\hline & Many times, I feel very connected with God. & .835 & & & \\
\hline 18. & I am living out God's will for my life in this world. & .805 & & & \\
\hline 6. & When I encounter God, I usually feel a oneness with God. & .773 & & & \\
\hline & I feel that my life is in tune with God. & .754 & & & \\
\hline & I find it easy to relate to the Higher Power. & .651 & & & \\
\hline & I feel that my life is in harmony with something that is greater than myself. & .484 & & & \\
\hline 27. & I am able to see the good side of other people. & & .676 & & \\
\hline 29. & When I am with other people, it's pretty easy to feel a connection with them. & & .637 & & \\
\hline & When I am around other people, I feel a harmony with them. & & .629 & & \\
\hline 25 . & $\begin{array}{l}\text { When dealing with problems, I tend to believe that things will eventually } \\
\text { work out for the best. }\end{array}$ & & .611 & & \\
\hline & I find it easy to forgive others who have wronged me. & & .596 & & \\
\hline & I tend to get along well with most everyone. & & .585 & & \\
\hline & I feel a closeness with people in my life. & & .512 & & \\
\hline & My life doesn't seem to have much purpose.* & & & .736 & \\
\hline 30 . & I often feel lost from a sense of direction in this world.* & & & .666 & \\
\hline & I don't know why I am in this world.* & & & .619 & \\
\hline & I find meaning and purpose in living my life in this world. & & & .611 & \\
\hline & I often feel lost from God.* & & & .525 & \\
\hline & I feel at peace with my family, friends, and most other people. & & & .471 & \\
\hline & I usually feel in synch with what is going on around me. & & & .423 & \\
\hline & I know my place in this world. & & & & .470 \\
\hline & I don't usually feel annoyed by other people.* & & & & .390 \\
\hline 19. & I am living in this world the way that I believe I should. & & & & .335 \\
\hline
\end{tabular}

$*=$ Con-trait item 
Since our goal was to develop a brief scale suitable for research, we decided to select 16 items from the first 3 factors based on two criteria: (1) items should represent a good sampling of content with respect to the meaning of the factor and (2) the strength of factor loadings should be considered as much as possible with concern for the first criterion. We selected the first 8 items $(26,22,16,14,20,28$, 12, and 8) from Factor 1 as they seemed a good representation of content associated with deistic spirituality; they also were the items with the highest loadings on the factor. From Factor 2, we selected the four items (27, 29, 23, and 17) that seemed to best characterize spiritual maturity in relating with others. From Factor 3, we gave priority to selecting the four items that represented the concern for existential attunement in the most diverse way; as stated above, the strength of factor loadings was of secondary concern, particularly so in this case. Even though both Items 21 and 11 characterized concern for finding purpose in life, Item 11, which loaded with less magnitude, includes the word "meaning," which broadened the content; thus we selected Item 11 instead of Item 21. From Factor 3, we selected Items 30, 5, 11, and 7.

Table 2 .

Final Factorial Structure, Descriptive Coefficients, and Reliabilities of the 16-Item Bidirectional Spirituality Scale Based on Exploratory Factor Analysis $(\mathrm{N}=239)$

\begin{tabular}{|c|c|c|c|c|c|}
\hline \multirow{2}{*}{$\frac{\text { Item }}{\#}$} & \multirow[b]{2}{*}{ Items } & \multicolumn{3}{|c|}{ Factors } & \multirow[b]{2}{*}{$\alpha$} \\
\hline & & $\mathbf{I}$ & II & III & \\
\hline & Bidirectional Spirituality Scale (BSS, 16 items; $M=84.27, S D=18.65)$ & & & & .92 \\
\hline & Vertical Spirituality (VS, 8 items; $M=43.2, S D=13.68)$ & & & & .97 \\
\hline 20. & I know beyond all doubt that God loves me. & .902 & & & \\
\hline 26. & When I engage in spiritual or religious practices, I feel drawn to God. & .898 & & & \\
\hline 22. & I often have the sense that God is with me. & .888 & & & \\
\hline 14. & I am fully confident that God is directing my life. & .880 & & & \\
\hline 28. & I feel a peacefulness when I think about God. & .875 & & & \\
\hline 12. & I know that God hears me when I pray. & .870 & & & \\
\hline 16. & I often feel close to God. & .868 & & & \\
\hline \multirow[t]{3}{*}{8.} & Many times, I feel very connected with God. & .810 & & & \\
\hline & Horizontal Spirituality (HS = HS-O + HS-E, 8 items; $M=41.07, S D=7.97)$ & & & & .78 \\
\hline & Horizontal Spirituality - Others (HS-O, 4 items; $M=21.47, S D=4.41)$ & & & & .74 \\
\hline 27. & I am able to see the good side of other people. & & .725 & & \\
\hline 23. & I find it easy to forgive others who have wronged me. & & .606 & & \\
\hline 17. & I tend to get along well with most everyone. & & .599 & & \\
\hline \multirow[t]{2}{*}{29.} & When I am with other people, it's pretty easy to feel a connection with them. & & .586 & & \\
\hline & Horizontal Spirituality - Existential (HS-E, 4 items; $M=19.6, S D=5.12$ ) & & & & .75 \\
\hline 30. & I often feel lost from a sense of direction in this world.* & & & .651 & \\
\hline 5. & I don't know why I am in this world.* & & & .649 & \\
\hline 11. & I find meaning and purpose in living my life in this world. & & & .648 & \\
\hline 7. & I usually feel in synch with what is going on around me. & & & .489 & \\
\hline
\end{tabular}

* = Con-trait item

Note: BSS = Bidirectional Spirituality Scale; VS = Vertical Spirituality; HS = Horizontal Spirituality;

HS-O = Horizontal Spirituality-Others; HS-E = Horizontal Spirituality-Existential 
Once item selection was completed, we subjected the 16 items to a second EFA using again the principal axis factoring method of extraction with varimax rotation. The scree plot (eigenvalues $>1$ ) revealed a solution of 3 factors that accounted for $64.06 \%$ (Factor $1=39.79 \%$, Factor $2=12.60 \%$, Factor $3=11.67 \%$ ) of the variance. As expected, Table 2 shows all items loaded on the appropriate factors with sufficient magnitudes of strength $(>.40)$. We conducted reliability analyses to examine the internal consistency of the entire BSS (16 items), VS (8 items), HS-O (4 items), HS-E (4 items), and Horizontal Spirituality (HS, 8 items, which is the combination of HS-O and HS-E). As presented in Table 2, all reliabilities indicate adequate internal consistency for all scales/factors. Table 2 also reports the means and standard deviations for all scales/factors.

\section{Partial Confirmatory Factor Analysis (PCFA)}

To further test the fit of the model to the data, we conducted a PCFA of the 16 BSSitems using SPSS software as outlined by Gignac (2009). Accordingly, the value of such a procedure is that the results can provide justification for recommending future research with another sample to validate an EFA-derived model using full confirmatory factor analysis. To perform the procedure, we entered the 16 items and selected maximum likelihood as the method of extraction and varimax rotation. The three-factor structure of the BSS derived by the EFA was confirmed by the PCFA. Using Bartlett's Sphericity Test (Null model $\chi^{2}$ ) and Goodness of Fit (Implied model $\left.\chi^{2}\right)$ statistics, we calculated the close-fit index values for the normed-fit index (NFI), comparative-fit index (CFI), Tucker-Lewis index (TLI), and root mean square error of approximation (RMSEA) as outlined by Gignac (2009). Gignac (p. 41) recommended that the NFI, CFI, and TLI values that are approximately .95 or larger and RMSEA values that are approximately .08 or less indicate an acceptable fit of the model to the data; however, others (e.g., Kelloway, 1998, p. 27) have argued that close-fit indices of .90 or greater and RMSEA values less than .10 indicate good fit for the model. Based on these latter criteria, the fit indices presented in Table 3 indicate good fit of the Bidirectional Spirituality model to the data.

Table 3.

Partial Confirmatory Factor Analysis Fit Indices for the Bidirectional Spirituality model $(\mathrm{N}=239)$

\begin{tabular}{cccccc}
\hline $\begin{array}{c}\text { Bartlett's Test of Sphericity } \\
\text { (Null model) } \chi^{2} / \boldsymbol{d} \boldsymbol{f}\end{array}$ & $\begin{array}{c}\text { Goodness of Fit } \\
\text { (Implied model) } \chi^{2} / \boldsymbol{d} \boldsymbol{f}\end{array}$ & $\boldsymbol{N F I}$ & $\boldsymbol{C F I}$ & $\boldsymbol{T L I}$ & $\boldsymbol{R M S E A}$ \\
\hline $3166.227 / 120^{*}$ & $242.368 / 75^{*}$ & .923 & .945 & .912 & .097 \\
\hline$* p<.001$ & & & & &
\end{tabular}

\section{BSS and Scale/Factor Correlations}

In preparing the initial items for the BSS, we assumed that factors would likely be orthogonal for a general sample that includes both religious and non-religious 
participants. In view of this, our focus here is largely on the relationships between the three spirituality scales/factors (VS, HS-O, HS-E). As presented in Table 4a, the correlations for VS X HS-O $(r=.32 ; p<.01)$ and VS X HS-E $(r=.42 ; p<.01)$, and for HS-O X HS-E $(r=.40, p<.01)$ are not large in magnitude, which suggests some degree of independence. In addition to these empirically-derived subscales, we constructed an 8-item Horizontal Spirituality (HS) scale, which might be useful in research, by combining the HS-O and HS-E factors. The size of the correlation for VS X HS-E $(r=.45, p<.01)$ also suggests some degree of independence.

Table 4a.

Correlations Between the Bidirectional Spirituality Scale and Scales/Factors $(\mathrm{N}=239)$

\begin{tabular}{lcccc}
\hline Factors & VS & HS & HS-O & HS-E \\
\hline BSS & $.92^{*}$ & $.75^{*}$ & $.58^{*}$ & $.67^{*}$ \\
VS & - & $.45^{*}$ & $.32^{*}$ & $.42^{*}$ \\
HS & - & - & $.81^{*}$ & $.86^{*}$ \\
HS-O & - & - & - & $.40^{*}$ \\
\hline
\end{tabular}

$* p<.001$

BSS = Bidirectional Spirituality Scale; VS = Vertical Spirituality; HS = Horizontal Spirituality;

HS-O = Horizontal Spirituality-Others; HS-E = Horizontal Spirituality-Existential

For religious people in general, however, we would expect VS to be more strongly related to the dimensions of HS-O and HS-E - much more so than for non-religious people. To investigate this hypothesis, we divided our sample into subgroups of religious $(n=207)$ and non-religious $(n=32)$ participants. For each of the groups, we computed descriptive coefficients for the scales/factors and also correlations between these scales/factors (see Table 4b). Not surprisingly, the religious $(M=47.09, S D=$ 9.20) scored significantly higher than the non-religious $(M=18.01, S D=10.87)$ on the VS factor, which is reflected in their overall BSS scores and its factors, although both groups are much more similar in scores on the HS-O, HS-E, and HS factors.

When comparing correlations between VS and the dimensions of the HS-O and HS-E from the entire sample (Table 4a) with those for the religious and non-religious subgroups (Table $4 \mathrm{~b}$ ), we found changes in magnitude that might be expected. For the religious, the correlation for VS X HS-E $(r=.52, p<.01)$ is considerably larger in size, while that for VS X HS-E $(r=.44, p<.01)$ is somewhat larger. For the nonreligious, however, these correlations are much smaller in size and not significant (VS $\mathrm{X}$ HS-O, $r=.08, p=.669$; VS X HS-E, $r=.28, p=.123$ ). Concerning the correlations for VS X HS (the composite of HS-O + HS-E), they are also larger in magnitude for the religious $(r=.57, p<.01)$, but again decreased in size to being insignificant for the non-religious $(r=.24, p=.186)$. Over all, the comparison between the entire sample and the religious and non-religious subsamples shows the correlations between VS and the dimensions of horizontal spirituality (HS-O, HS-E, HS) to have remained significant and even increased in magnitude for religious participants, but to have decreased in size and become insignificant for non-religious participants. 
Table 4b.

Correlations Between the Bidirectional Spirituality Scale and Scales/Factors; Descriptive Coefficients for Religious ( $\mathrm{n}=207)$ and Non-Religious Participants $(\mathrm{n}=32)$

\begin{tabular}{lcccccc}
\hline Factors & BSS & VS & HS & HS-O & HS-E & M/SD \\
\hline BSS & - & $.91^{*}$ & $.87^{*}$ & $.75^{*}$ & $.71^{*}$ & $88.57 / 15.10$ \\
VS & $.84^{*}$ & - & $.57^{*}$ & $.52^{*}$ & $.44^{*}$ & $47.09 / 9.20$ \\
HS & $.73^{*}$ & .24 & - & $.83^{*}$ & $.86^{*}$ & $41.47 / 7.83$ \\
HS-O & $.46^{*}$ & .08 & $.73^{*}$ & - & $.42^{*}$ & $21.49 / 4.45$ \\
HS-E & $.69^{*}$ & .28 & $.88^{*}$ & .33 & - & $19.98 / 4.85$ \\
$\boldsymbol{M} / \boldsymbol{S D}$ & $56.48 / 15.32$ & $18.01 / 10.87$ & $38.47 / 8.50$ & $21.34 / 4.20$ & $17.13 / 6.13$ & - \\
\hline$* p<.01$ & & & & & &
\end{tabular}

$* p<.01$

Note: Religious participant correlations are reported above the hash marks; non-religious participant correlations are reported below the hash marks.

BSS = Bidirectional Spirituality Scale; VS = Vertical Spirituality; HS = Horizontal Spirituality;

HS-O = Horizontal Spirituality-Others; HS-E = Horizontal Spirituality-Existential

What these findings suggest on the one hand is that the spirituality that religious participants experience in relation to their God is reflected strongly in their relationships with people - in other words, the former may flow into the latter. On the other hand, although the non-religious may enjoy a spiritual connection with others and may be spiritually attuned to their sense of place in the world, this is not derived from a vertical relationship with God.

\section{Evidence for Validity}

The preliminary construct validity for the BSS, which has been established above, is assisted with evidence for both convergent and discriminant validity (Kaplan \& Saccuzzo, 2009, pp. 147-153). We developed BSS items such that higher scores would reflect increased spiritual attunement to God, other people, and existential concerns. Those with higher BSS scores, therefore, should score higher in mysticism, selfesteem, happiness, life satisfaction, and optimism and score lower in depression, weak ego strength, worry, and pessimism. We also anticipated that higher scores on the BSS would relate to higher reports of intrinsic and, to a lesser degree, extrinsic religiosity.

Correlations between BSS/factors and the above variables are reported in Table 5. Because of the large sample size and its statistical power to detect even weak relationships, we set the alpha level of significance for relationships at $p<.01$. Concerning the full measure of the BSS, all validity coefficients are significant in the expected direction except for worry $(r=-.17, p>.01)$, although they were of various magnitudes (from $r=.23$ to .69 [absolute values], $p<.01$ ). 
Table 5 .

Validity Correlations for the Bi-directional Spirituality Scale and Sub-factors $(\mathrm{N}=239)$

\begin{tabular}{|c|c|c|c|c|c|}
\hline \multirow{2}{*}{$\begin{array}{c}\text { Study Variables } \\
\text { Convergent Validity Measures }\end{array}$} & \multicolumn{5}{|c|}{ BDSS and Sub-factors } \\
\hline & BDSS & VS & HS & HS-O & HS-E \\
\hline God Mysticism (Hood \& Williamson, 2000) & $.69^{*}$ & $.72 *$ & $.37 *$ & $.27 *$ & $.34 *$ \\
\hline Self-esteem (Rosenberg, 1965) & $.41^{*}$ & $.22 *$ & $.59 *$ & $.33^{*}$ & $.62 *$ \\
\hline Happiness (Lyubomirsky \& Lepper, 1999) & $.51^{*}$ & $.40^{*}$ & $.51 *$ & $.41 *$ & $.44^{*}$ \\
\hline Optimism (Scheier et al., 1994) & $.40^{*}$ & $.24^{*}$ & $.53^{*}$ & $.42 *$ & $.46^{*}$ \\
\hline Life satisfaction (Diener et al., 1985) & $.33^{*}$ & $.24^{*}$ & $.38 *$ & $.21 *$ & $.41^{*}$ \\
\hline \multicolumn{6}{|l|}{ Discriminant Validity Measures } \\
\hline Depression (Beck et al., 1961) & $-.44 *$ & $-.28 *$ & $-.55^{*}$ & $-.32 *$ & $-.58 *$ \\
\hline Ego Loss (Kohls et al., 2008) & $-.29 *$ & -.16 & $-.40 *$ & $-.18 *$ & $-.46^{*}$ \\
\hline Worry (Meyer et al., 1990) & -.17 & -.06 & $-.29 *$ & $-.20 *$ & $-.28 *$ \\
\hline Pessimism (Scheier et al., 1994) & $-.23 *$ & $-.17 *$ & $-.24 *$ & -.15 & $-.25 *$ \\
\hline \multicolumn{6}{|l|}{ Religious Motivation } \\
\hline Intrinsic (Gorsuch \& McPherson, 1989) & $.57 *$ & $.63^{*}$ & $.24 *$ & $.17^{*}$ & $.22 *$ \\
\hline Extrinsic (Gorsuch \& McPherson, 1989) & $.25^{*}$ & $.30^{*}$ & .06 & -.01 & .10 \\
\hline \multicolumn{6}{|c|}{$\begin{array}{l}* p<.001 \text { (Note that for the coefficient of } .17 \text {, two relationships are significant, while one is no } \\
\text { to rounding.) } \\
\text { BSS = Bidirectional Spirituality Scale; VS = Vertical Spirituality; HS = Horizontal Spirituality; } \\
\text { HS-O = Horizontal Spirituality-Others; HS-E = Horizontal Spirituality-Existential }\end{array}$} \\
\hline
\end{tabular}

Because the BSS assesses two distinct dimensions of spirituality, perhaps a more useful procedure for examining scale validity is to attend the coefficients reported in the columns for VS and HS. For both dimensions, convergent-validity coefficients are all positive and significant and range from approaching moderate $(r=.22)$ to large $(r=$ .72) magnitudes. Concerning discriminant validity, more evidence exists for HS than for VS. All discriminant validity coefficients are significant and negatively related to HS, ranging in magnitude from -.25 to -.58 . However, only two of these coefficients are significant and negatively related to VS: Pessimism $(r=-.17)$ is weakly related, and depression $(r=-.28)$ is near-moderately related. In observing the columns for the HS-O and HS-E - which constitute the HS - even more discriminating and interesting information exists. For example, all validity variables are more strongly related to spiritual attunement to one's existential place in the world (HS-E) than to spiritual relations with others (HS-O). As expected, intrinsic religious motivation is most strongly associated with the BSS and is significant across all factors, whereas extrinsic orientation is less related to the BSS and VS, and unrelated to the other factors. Thus these analyses indicate the initial evidence for both convergent and discriminant validity of the BSS to be a measure of bidirectional spirituality.

\section{Discussion}

This study has been concerned with developing a brief instrument that is theoretically grounded for assessing the vertical and horizontal dimensions of spirituality (Streib \& Hood, 2016). Analyses of the data derived a 16-item scale with three factors of vertical spirituality (VS), horizontal spirituality-others (HS-O), and horizontal spirituality- 
existential (HS-E) with good internal consistency and initial evidence for validity. Furthermore, the bidirectional construction of this instrument allows for spiritual assessment with both religious and non-religious groups. It is useful with religious groups in that it relates to both their vertical and horizontal dimensions of spirituality; for them, a spiritual relationship with God likely flows into their spiritual relations with other people and affords them a sense of meaning and purpose in life. The BSS also seems useful with non-religious groups who might not relate to a God-based spirituality but otherwise experience a spiritual connection with other people and find themselves spiritually in attunement with a sense of purpose and meaning in life.

The findings of the present study have indicated the BSS to have sound psychometric properties. Furthermore, our findings from the partial confirmatory factor analysis (Gignac, 2009) warrant the need for further investigation with a different sample using a full confirmatory factor analysis. Such a study would further establish the construct validity of the BSS as a measure of bidirectional spirituality. Nevertheless, this study indicates that the BSS holds promise as a brief, multidimensional scale for research on religious and non-religious spirituality (see Appendix).

\section{References}

Beck, A.T., Ward, C.M., Mendelson, M., Mock, J., \& Erbaugh, J. (1961). An inventory formeasuring depression. Archives of General Psychiatry, 4, 561-571.

Bufford, R. K., Paloutzian, R. F., \& Ellison, C. W. (1991). Norms for the Spiritual Well-Being Scale. Journal of Psychology and Theology, 19, 56-70.

Daaleman, T. P., \& Frey, B. B. (2004). The spirituality index of well-being: A new instrument for health-related quality of life research. Annals of Family Medicine, 2, 499-503.

Davis, D. E., Rice, K., Hook, J. N., Van Tongeren, D. R., DeBlaere, C., Choe, E., \& Worthington, Jr., E. L. (2015). Development of the Sources of Spirituality Scale. Journal of Counseling Psychology, 62, 503-513.

Delaney, C. (2005). The Spirituality Scale development and psychometric testing of a holistic instrument to assess the human spiritual dimension. Journal of Holistic Nursing, 23, 145-167.

Diener, E., Emmons, R. A., Larsen, R. J., \& Griffin, S. (1985). The Satisfaction with Life Scale. Journal of Personality Assessment, 49, 71-75.

Ekşi, H., \& Kardaş, S. (2017). Spiritual well-being: Scale development and validation. Spiritual Psychology and Counseling, 2, 73-88.

Fang, C. K, Li, P. Y., Lai, M. L., Lin, M. H., Bridge, D. T., \& Chen, H. W. (2011). Establishing a "physician's spiritual well-being scale" and testing its reliability and validity. Journal of Medical Ethics, 37, 6-12.

Fisher, J. W. (1998). Spiritual health: Its nature, and place in the school curriculum (Unpublished doctoral dissertation). University of Melbourne, Melbourne, Victoria, Australia.

Gignac, G. E. (2009). Partial confirmatory factor analysis: Described and illustrated on the NEOPI-R. Journal of Personality Assessment, 91, 40-47. 
Gomez, R., \& Fisher, J. W. (2003). Domains of spiritual well-being and development and validation of the Spiritual Well-Being Questionnaire. Personality and Individual Differences, 35, 1975-1991.

Gorsuch, R.L., \& McPherson, S.E. (1989). Intrinsic/extrinsic measurement: I/I-revised and singleitem scales. Journal for the Scientific Study of Religion, 28, 348-354.

Hood, R. W., Jr., Hill, P. C., \& Spilka, B. (2009). The psychology of religion: An empirical approach ( $4^{\text {th }}$ ed.). New York: Guilford Press.

Hood, R.W., Jr., \& Williamson, W.P. (2000). An empirical test of the unity thesis: The structure of mystical descriptors in various faith samples. Journal of Psychology and Christianity, 19(3), 232-244.

James, W. (1982). The varieties of religious experience. New York: Penguin. (Original work published in 1902)

Kaplan, R. M., \& Saccuzzo, D. P. (2009). Psychological testing: Principles, applications, and issues ( $7^{\text {th }}$ ed.). Belmont, CA: Wadsworth, Cengage Learning.

Kelloway, E. K. (1998). Using LISREL for structural equation modeling. Thousand Oaks, CA: Sage Publications.

Kohls, N., Hack, A., \& Walach, H. (2008). Measuring the unmeasureable to tickin boxes and actually opening Pandora's box? Mixed methods research as a useful tool for investigating exceptional human experiences. Archive for the Psychology of Religion, 30, 155-187.

Ledbetter, M. F., Smith, L. A., Fischer, J. D., Vosler-Hunter, W. L., \& Chew, G. P. (1991). An evaluation of the construct validity of the Spiritual Well-Being Scale: A confirmatory factor analytic approach. Journal of Psychology and Theology, 19(1), 94-102.

Lyubomirsky, S., \& Lepper, H. S. (1999). A measure of subjective happiness: Preliminary reliability and construct validation. Social Indicators Research, 46, 137-155.

Meyer, T. J., Miller, M. L., Metzger, R. L., \& Borkovec, T. D. (1990). Development and validation of the Penn State Worry Questionnaire. Behaviour Research and Therapy, 28, 487-495.

Paloutzian, R. F., \& Ellison, C. W. (1982). Loneliness, spiritual well-being and the quality of life. In L. A. Peplau \& D. Perlman (Eds.), Loneliness: A sourcebook of current theory, research and therapy (pp. 224-237). New York: Wiley.

Peterman, A. H., Fitchett, G., Brady, M. J., Hernandez, L., \& Cella, D. (2002). Measuring spiritual well-being in people with cancer: The Functional Assessment of Chronic Illness TherapySpiritual Well-Being scale (FACIT-Sp). Annals of Behavioral Medicine, 24, 49-58.

Piedmont, R. L. (1999). Does spirituality represent the sixth factor of personality? Spiritual transcendence and the Five-Factor Model. Journal of Personality, 67, 985-1014.

Piotrowski, J., Skrzypińksa, K., \& Żemojtel-Piotrowska, M. (2013). The Scale of Spiritual Transcendence: Construction and validation. Annals of Psychology, 16, 469-485.

Rosenberg, M. (1965). Society and the adolescent self-image. Princeton, NJ: Princeton University Press.

Scheier, M. F., Carver, C. S., \& Bridges, M. W. (1994). Distinguishing optimism from neuroticism (and trait anxiety, self-mastery, and self-esteem): A re-evaluation of the Life Orientation Test. Journal of Personality and Social Psychology, 67, 1063-1078.

Scott, E. L., Agresti, A. A., \& Fitchett, G. (1998). Factor analysis of the Spiritual Well-Being Scale and its clinical utility with psychiatric inpatients. Journal for the Scientific Study of Religion, 37, 314-321.

Streib, H., \& Hood, R. W., Jr. (2016). Understanding spirituality: Conceptual considerations. In H. Streib \& R. W. Hood, Jr. (Eds.), Semantics and psychology of spirituality: A cross-cultural analysis (pp. 3-17). New York: Springer. 
Vivat, B., Young, T., Efficace, F., Sigurdadóttir, V., Arraras, J. I., Åsgeirsdóttir, G. H., ... the EORTC Quality of Life Group. (2013). Cross-cultural development of the EORTC QLB-SWB36: A stand-alone measure of spiritual well-being for palliative care patients with cancer. Palliative Medicine, 27, 457-469.

Williamson, W. P., \& Hood, R. W., Jr. (2016). Psychology and spiritual transformation in a substance abuse program: The Lazarus Project. Lanham, MD: Lexington Books.

World Health Organization. (2002). WHOQOL Spirituality, Religiousness and Personal Beliefs (SRPB) Field-Test instrument. Geneva: Department of Mental Health and Substance Dependence, World Health Organization. Online available at www.who.int/mental_health/media/en/622.pdf

Zinnbauer, B. J., \& Pargament, K. I. (2005). Religiousness and spirituality. In C. L. Park \& R. F. Paloutzian (Eds.), Handbook of the psychology of religion and spirituality (pp. 21-42).

\section{Appendix}

Below are the instructions and recommended presentation order of the Bi-directional Spirituality Scale for future research.

Instructions: Please read each statement below very carefully and rate your level of agreement on how it relates to your personal life. Do not make your judgement based on how you would like it to relate to you, but how it honestly relates to you.

$$
\begin{aligned}
& 1=\text { Strongly disagree } \\
& 2=\text { Moderately disagree } \\
& 3=\text { Slightly disagree } \\
& 4=\text { Uncertain } \\
& 5=\text { Slightly agree } \\
& 6=\text { Moderately agree } \\
& 7=\text { Strongly agree }
\end{aligned}
$$

1. I know beyond all doubt that God loves me.

2. I am able to see the good side of other people.

3. When I engage in spiritual or religious practices, I feel drawn to God.

4. I often feel lost from a sense of direction in this world.*

5. I often have the sense that God is with me.

6. I find it easy to forgive others who have wronged me.

7. I am fully confident that God is directing my life.

8. I don't know why I am in this world.*

9. Many times, I feel very connected with God.

10. I tend to get along well with most everyone.

11. I know that God hears me when I pray.

12. I find meaning and purpose in living my life in this world.

13. I often feel close to God.

14. When I am with other people, it's pretty easy to feel a connection with them.

15. I feel a peacefulness when I think about God.

16. I usually feel in synch with what is going on around me.

* Con-trait items are to be reverse-scored. 
